\title{
Comunicação
}

[Communication]

\section{Comparação sérica e sangüínea do cálcio ionizado, sódio, potássio e cloreto em felinos pelo método eletrodo íon seletivo}

\author{
[Serum and blood comparison of ionized calcium, sodium, potassium and chloride in cats, \\ by ion-selective electrode method] \\ L.H. Giovaninni ${ }^{1}$, M.M. Kogika ${ }^{2}$, M.D. Lustoza ${ }^{1}$, K.K. Kanayama ${ }^{2}$, A. Reche Júnior ${ }^{2}$ \\ ${ }^{1}$ Aluno de pós-graduação - FMVZ-USP - São Paulo, SP \\ ${ }^{2}$ Faculdade de Medicina Veterinária e Zootecnia - USP - São Paulo, SP
}

Há estreita variação fisiológica dos valores eletrolíticos, e as mais variadas condições mórbidas podem acarretar alterações destes valores, desequilibrando o balanço dos eletrólitos (DiBartola et al., 1994; Kavanagh e Mills, 1997). O método eletrodo íon seletivo (MEIS) é indicado para a mesuração, sérica e sangüínea, dos eletrólitos e do cálcio ionizado (DiBartola et al., 1994); seu princípio consiste na existência de membranas específicas sensíveis aos diferentes íons que, em contato com uma solução de referência e com a amostra a ser analisada, mede a diferença de potencial elétrico e, conseqüentemente, a concentração do íon (Kavanagh e Mills, 1997; Burnett, et al., 2000). O MEIS utiliza amostras de pequeno volume, apresenta resultados rápidos, é de simples manuseio, mensurando apenas as partículas ionizadas dos eletrólitos, não apresentando interferências nos resultados em conseqüência de alterações da amostra, como lipemia, hemólise e icterícia (Christopher et al., 1996). Kavanagh e Mills (1997) recomendam que cada equipamento de eletrodo íon seletivo deve ter os valores de referência especificamente determinados.

O presente estudo teve por objetivo comparar os valores séricos e sangüíneos de sódio, cálcio ionizado, potássio e cloreto obtidos pelo MEIS.

Foram selecionados 55 gatos, com idades entre 8 e 136 meses, 18 machos e 37 fêmeas, de definições raciais variadas e sem raça definida, considerados hígidos segundo o histórico, exame físico e exames laboratoriais (hemograma e valores séricos de uréia e creatinina). De cada animal foi colhida uma amostra de $3 \mathrm{ml}$ de sangue venoso, no período matutino, após jejum alimentar de 12 horas, a qual foi acondicionada em frasco isento de íons e a vácuo (Vacutainer ${ }^{\circledR}$ siliconizado com gel), sendo centrifugada por 10 minutos em $1700 \mathrm{G}$ para a obtenção do soro, no qual mensuraram-se o sódio, o cálcio ionizado, o potássio e o cloreto pelo MEIS em analisador automático de eletrólitos marca AVL modelo OMNI-4. Neste mesmo momento de colheita obteve-se uma outra amostra de $0,5 \mathrm{ml}$ sangue venoso, em seringa plástica que continha heparina liofilizada com lítio (COMBIsampler $\AA$, Vented syringe kits - AVL) na qual realizaram-se as mensurações sangüíneas de sódio, cálcio ionizado, potássio e cloreto pelo MEIS em analisador automático de eletrólitos marca AVL, modelo OMNI-4.

Para a avaliação estatística utilizou-se o programa estatístico SigmaStat, versão 3,1, empregando-se o teste Kolmogorov-Smirnov, segundo os preceitos de Sampaio (1998), com o intuído de verificar se os dados obtidos apresentavam distribuição gaussiana. De acordo com a distribuição gaussiana ou não, realizaramse testes estatísticos paramétricos ( $\mathrm{t}$ de "student") ou não paramétricos (Mann-Whitney),

Recebido em 22 de agosto de 2006

Aceito em 15 de abril de 2007

Endereço para correspondência (corresponding address)

02043-081 - São Paulo, SP

E-mail: ihgiovaninni@yahoo.com.br 
respectivamente. Assim, o teste paramétrico foi empregado para a análise dos valores de potássio, sódio e cloreto, e o teste não paramétrico, para os valores de cálcio ionizado. Independentemente do teste empregado considerou-se como diferença significante quando $\mathrm{P}<0,05$.

Em relação ao valor do sódio, não houve diferença significativa $(\mathrm{P}=0,102)$ entre as determinações realizadas no soro $(151,7 \pm 4,5 \mathrm{mmol} / \mathrm{l})$ e no sangue $(152,5 \pm 5,8 \mathrm{mmol} / 1)$. O sódio é o cátion de maior concentração no meio extracelular (Senior, 1992) e, provavelmente, devido a este fato, não houve variação das concentrações mensuradas nos diferentes tipos de amostra.

Os valores de cálcio ionizado apresentaram diferença $(\mathrm{P}=0,0132)$. $\mathrm{O}$ valor do cálcio ionizado sérico $(5,2 \pm 0,34 \mathrm{mg} / \mathrm{dl})$ foi, em média, $3,7 \%$ menor que o do cálcio ionizado obtido no sangue $(5,4 \pm 0,45 \mathrm{mg} / \mathrm{dl})$, o que pode ser justificado pelo fato de que, mesmo nas condições de anaerobiose em que o soro foi obtido, a sua manipulação no momento das dosagens pode ter permitido o contato com o ar atmosférico, o que possibilitaria a perda de dióxido de carbono e o conseqüente aumento do $\mathrm{pH}$ do soro, contribuindo para a diminuição das concentrações de cálcio ionizado das amostras séricas (Schenck, et al., 1995).
A diferença entre os valores de potássio obtidos no soro e no sangue foi altamente significativa $(\mathrm{P}<0,0001)$, isto é, em média, os valores séricos de potássio $(4,47 \pm 1,08 \mathrm{mmol} / \mathrm{l})$ foram $11,9 \%$ maiores que os de potássio no sangue $(3,94 \pm 1,01 \mathrm{mmol} / 1)$. A maior média obtida no soro pode ser justificada pela presença de hemólise microscópica, geralmente esperada no processo de centrifugação da amostra para a obtenção do soro, pois o potássio tem sua maior concentração no meio intracelular (Meyer, 1995).

$\mathrm{O}$ cloreto $(\mathrm{P}=0,0045)$ foi o eletrólito estudado que, na média, apresentou a menor diferença, pois os valores obtidos no soro $(117,2 \pm 6,06 \mathrm{mmol} / \mathrm{l})$ foram apenas $1,4 \%$ maiores que aqueles obtidos no sangue $(115,6 \pm 5,56 \mathrm{mmol} / \mathrm{l})$.

De acordo com os dados obtidos no presente estudo, observou-se que os valores das concentrações séricas e sangüíneas de cálcio ionizado, potássio e cloreto, obtidos de felinos e mensurados pelo MEIS foram diferentes, Assim, recomenda-se que, para a avaliação desses íons pelo MEIS, proceda-se à prévia determinação de valores de referência de acordo com o tipo de amostra.

\begin{abstract}
Values of sodium, ionized calcium, potassium and chloride obtained by ion-selective electrode method, from serum and blood samples of healthy cats, were compared. Serum ionized calcium value was lower $(5.2 \mathrm{mg} / \mathrm{dl})$ than blood ionized calcium $(5.4 \mathrm{mg} / \mathrm{dl})$, and serum potassium $(4.47 \mathrm{mmol} / \mathrm{l})$ and serum chloride (117.2mmol/l) values were higher than blood potassium (3.94mmol/l) and blood chloride (115mmol/l).
\end{abstract}

Keywords: cat, calcium, chloride, sodium, potassium

\section{REFERÊNCIAS BIBLIOGRÁFICAS}

BURNETT, R.W.; COVINGTON, A.K.; FOGHANDERSEN, N. et al. Use of ion-selective electrodes for blood-electrolyte analysis. Recommendations for nomenclature, definitions and conventions. International Federation of Clinical Chemistry and Laboratory Medicine (IFCC). Scientific Division Working Group on Selective Electrodes. Clin. Chem. Lab. Med., v.38, p.363-370, 2000.

CHRISTOPHER, M.M.; BELKNAP, B.E.; MEYER, D.J. et al. Comparison of methods for sodium and potassium determination in llama urine. Am. J. Vet. Res., v.57, p.25-30, 1996.
DiBARTOLA, S.P.; GREEN, R.A.; MORAIS, H.S.A. Electrolytes and acid base. In: WILLARD, M.D.; TVEDTEN, H.; TURWALD, G.H. Small animal clinical diagnosis in laboratory methods. 2.ed. Philadelphia: W.B. Saunders, 1994. p.97-113.

KAVANAGH, K.; MILLS, J.N. Measuring electrolytes: An evaluation of the IDEXX Vetlyte ion selective electrode method. Aust. Vet. Pract., v.27, p.97-102, 1997.

MEYER, D.J.; COLES, E.H.; RICH, L.J. Medicina de laboratório veterinária: interpretação e diagnóstico. São Paulo: Editora Roca, 1995. p.83-90. 
OESCH, U.; AMMANN, D.; SIMON, W. Ionselective membrane electrodes for clinical use. Clin. Chem., v.32, p.1448-1459, 1986.

SAMPAIO, I.B.M. Estatística aplicada à experimentação animal. Belo Horizonte: Fundação de Ensino e Pesquisa em Medicina Veterinária e Zootecnia, 1998. 221 p.
SCHENCK, P.A.; CEW, D.J.; BROOKS, C.L. Effects of storage on serum ionized calciumand $\mathrm{pH}$ values in clinically normal dogs. Am. J. Vet. Res., v.56, p.304-307, 1995.

SENIOR, D.F. Fluidoterapia, controle dos eletrólitos e acidobásico. In: ETTINGER, S.J. Tratado de medicina interna veterinária. 3.ed. São Paulo: Editora Manole, 1992. v.1, p.450-471. 